\title{
Qualities for early childhood care and education in an age of increasing superdiversity and decreasing biodiversity
}

Contemporary Issues in Early Childhood 2016, Vol. 17(1) 78-91 (C) The Author(s) 2016 Reprints and permissions: sagepub.co.uk/journalsPermissions.nav DOI: $10.1|77 /| 463949|| 5627905$ cie.sagepub.com

@SAGE

\section{Jenny Ritchie}

Victoria University of Wellington, New Zealand

\begin{abstract}
In this article it is argued that notions of 'quality' in early childhood education have been captured by neo-liberal discourses. These discourses perpetuate the western, individualistic, normativising and exploitative attitudes and practices that are contributing to the climate crisis currently imperilling our planet. Educators may inadvertently perpetuate this situation, or they can instead consciously challenge this dominant culture, opening up spaces of divergence. Via a sequence of short scenarios or stories based within the early childhood care and education context of Aotearoa (New Zealand), readers are invited to consider alternative conceptualisations, drawing on post-humanist and Indigenous theorising, which focus on fostering dispositional qualities that holistically engage intra-actively with(in) children's worlds.
\end{abstract}

\section{Keywords}

Aotearoa, cultural diversity, dispositions, early childhood care and education, Indigenous perspectives, Māori, post-humanism, superdiversity

\section{Introduction}

This article, in considering notions of 'quality' in early childhood care and education (ECCE), is also a response to a set of interrelated 'matters of concern' (Latour, 2004). The 'matters of concern' that are addressed here include: the 'othering' of Māori children and families by well-meaning early childhood teachers in New Zealand; the challenges to teachers in a demographic context of 'superdiversity'; the global climate crisis and its impact on biodiversity; and the difficulty of operating 'otherwise' within a neo-liberal policy framework. The current modernist, neo-liberal framing of notions of 'quality' is determined by superficial macro-analyses (Braidotti, 2013) and measured and constrained by blunt instruments such as the New Zealand 'national standards'. This 
notion is seductive in its promise of certainty, of knowable 'objectivity' and of universal consistency (Moss et al., 2000). Yet this homogeneous, hegemonic, humanist macro-understanding of 'quality' may be less helpful than a careful micro-focus on the qualities that are being fostered in ECCE, and the way these may prepare young children to face an uncertain future. ${ }^{1}$ I argue that such qualities need to engage a reorientation away from humanistic, individualist modes, to ways of seeing, feeling and being in the world that recognise human inter/dependence within the world.

The western economic system's reliance on fossil-fuelled technologies has generated multiple interrelated crises: social, environmental, economic and cultural (Cameron et al., 2013). Globally, huge numbers of people are dislocated by wars; biodiversity is increasingly endangered, with many species being lost annually; there is growing disparity between the rich and the poor, both between and within countries; and many peoples are in danger of losing their languages and cultural heritage. Anthropogenic climate change ultimately threatens all life on the planet (Goldenberg, 2014). This anthropocentric 'othering' by those members of privileged classes and privileged countries, of both humans who are not white and middle class and of the more-than-human world, is disabling our response-ability to act in concert with these 'others'. This article suggests that a post-humanist lens may help us to shift away from these hierarchical modernist anthropocentric instruments (Rose, 2009; Taylor and Pacini-Ketchabaw, 2015). It invites consideration of the ways we might model and inspire in those teachers we work with ways of being, relating, knowing and doing that reflect a sense of 'interbeing' with(in) the world (Hanh, 1991, 2008).

The article reconsiders the ways in which western humanist lenses have framed notions of quality from a hierarchical anthropocentric lens, categorising not only matter, but also what matters from this traditionally white, western, male-dominated paradigm. The notion of 'quality' in early childhood education has generated a regime of truth(s) that has served the purposes of education officials tasked with creating frameworks that might allegedly improve the delivery of services, but also ultimately serves the agendas of particular government policies. These frameworks have been produced from western, cognitivist, positivist theoretical paradigms that have unquestioningly privileged humanist ways of knowing, being, doing and relating. These are, borrowing from Karen Barad (2003), 'seductive habits of mind which are worth questioning' (802). Adopting a representationalist view of discourse is a further seduction perpetuated by such frameworks, since '[d]iscourse is not what is said; it is that which constrains and enables what can be said' (819). In this way, such frameworks may be more powerful in what they exclude than in what they include. Western perspectives in countries with a history of colonisation have historically excluded Indigenous ways of being, knowing, doing and relating. The post-humanist turn goes further, since, in Barad's account, all bodies - both non-human and human - are materialdiscursive phenomena and collectively 'come to matter through the world's iterative intra-activity - its performativity' (823).

A post-humanist lens no longer positions humans as unique in their capacity to work on the world. Instead, 'we are part of the world in its ongoing intra-activity' (Barad 2003: 828). Barad's conceptualisation rejects the artificial separation of ontology and epistemology, since '[w]e do not obtain knowledge by standing outside of the world; we know because "we" are of the world. We are part of the world in its differential becoming' (829). Similarly, the cosmology of Māori, the Indigenous peoples of Aotearoa (New Zealand), situates humans, trees, birds and other creatures as fellow descendants of Sky Father (Ranginui) and Mother Earth (Papatūānuku), on whom we all depend for our nurture and well-being. Viewing our work in early childhood education through such a post-humanist (and pre-western) lens creates possibilities for articulating an ethics of reaffirmation of our shared becomingness with the more-than-human, and our response-ability (Haraway, 2012) to act in the interests of our planet and all that cohabit with us in the world. 
Since the term 'quality' has been imbued with such universalising, normativising implications, in this article I propose that we refocus our gaze towards the qualities that facilitate our interdependent relationality as cohabiters of our planet. Drawing on examples from Aotearoa (New Zealand), I consider what qualities lie at the heart of pedagogies that offer counter-colonial reenvisaging, positing our response-ability for 'thinking-with' - that is, from a central awareness of our situatedness within these interrelationships - as a serious engagement and necessity in the face of the increasingly severe climate crisis of the Anthropocene - that is, the current era of humaninduced climate change (Haraway, 2012; Puig de la Bellacasa, 2012; Rose, 2009; Taylor and Pacini-Ketchabaw, 2015). Identifying and exploring these qualities challenges the complacency of relying on western, humanist, cognitivist paradigms for 'knowing' the 'Other' (Levinas, 1987), opening up instead possibilities for affirming ways of recognising sensorial embodied knowing within the more-than-human world as an ethical imperative (Ritchie, 2013).

I begin with some reflections drawing on the historical context for education in Aotearoa (New Zealand) and the New Zealand early childhood curriculum, Te Whāriki: He Whāriki Mātauranga mō ngā Mokopuna o Aotearoa (New Zealand Ministry of Education, 1996). This is followed by consideration of the ongoing struggle by the predominately non-Māori teacher workforce to implement this 'bicultural' curriculum. Three 'stories' related to quality/ies in ECCE in Aotearoa (New Zealand) are then provided in order to illustrate ways of opening up reconsideration of these notions from a range of alternative theoretical lenses.

\section{Te Whāriki and Te Tiriti o Waitangi}

Te Whāriki, the New Zealand early childhood education curriculum, released two decades ago in 1996, was groundbreaking in being both the first early childhood curriculum and the first bicultural curriculum for Aotearoa (New Zealand). Of major significance is its recognition of the ongoing status and significance of Te Tiriti o Waitangi, the 1840 treaty that allowed the British settlement of Aotearoa (New Zealand). In Article 1 of the Māori version of Te Tiriti o Waitangi, Māori agreed to governance by the British Crown, which then became a party to the treaty along with Māori chiefs, creating a notional 'partnership'. In 1852, the British Crown handed government over to the settlers, excluding Māori from participation in the law-making for their own country (until the 1867 Māori Representation Act granted the constrained representation of four Māori parliamentary seats). Māori, as approximately $16 \%$ of the current population, remain politically and socio-economically marginalised by the current majoritarian system of democracy. In Article 2 of the treaty, Māori were promised their tino rangatiratanga ('self-determination') over their lands and villages and taonga katoa ('everything of value', including the more-than-human world - the resources and systems that sustain all life). Article 3 stated that Māori would have equal citizenship rights to those of the (originally British) settlers.

Te Whāriki offers a paradigm that recognises the Indigenous/First Nations status of Māori alongside a vision of cultural equity for all children who are present, stating that: 'In early childhood education settings, all children should be given the opportunity to develop knowledge and an understanding of the cultural heritages of both partners to Te Tiriti o Waitangi' (New Zealand Ministry of Education, 1996: 9). It asks teachers to consider: 'In what ways do the environment and programme reflect the values embodied in Te Tiriti o Waitangi, and what impact does this have on adults and children?' (56). This could be read as a call to respond to the impetus in Article 2 of Te Tiriti, which signals the protection of the Māori language and culture, as well as the biodiversity Indigenous to Aotearoa, and the responsibility of Māori and others to actively engage in this. This commitment might further involve the fostering of dispositions or qualities of kaitiakitanga 
('custodianship') that enable caring for the forests, lands, rivers and seas, and the creatures that dwell within them.

The 'Belonging' strand of Te Whāriki requires that: 'Liaison with local tangata whenua [Indigenous people] and a respect for [P] apatuanuku should be promoted' (54). In Māori cosmology, people, plants, animals and other creatures are all descendants from Tane Māhuta, one of the Atua ('Gods') who are the children of Ranginui (the Sky Father) and Papatūānuku (the Earth Mother). This kinship 'was the revolving door between the human, physical, and spiritual realms' (Waitangi Tribunal, 2011: 5). The core kinship value of whanaungatanga ('relationships') emphasises the role of kaitiakitanga, the response-ability to nurture and care for the more-than-human taonga ('things of value'). This interconnectedness is reflected in te reo Māori ('the Māori language') and is particularly evident in the layerings of meanings for particular kupu ('words'). For example, the term whenua means both 'land' and 'placenta'. 'Therefore, the land has the same deep significance as the placenta, which surrounds the embryo. Giving it warmth and security, a mauri, a life force that relates to and interacts with Mother earth's forces' (Henare, 2010, cited in Jenkins and Harte, 2011: 8). After a Māori child is born, the whenua ('placenta') is buried on their whenua ('land'). Jenkins and Harte (2011: 8) consider that this semantic connection of the land, of the Earth Mother Papatūānuku, and the placenta 'indicates the spiritual interaction of the two'. Colonisation has disrupted these connections in multiple ways: through generations of Māori having been alienated from their lands; from their languages; from knowledge of their ancestral connections, lineages and knowledges; and from actively participating in rituals enabling of their spiritual interconnectedness (Walker, 2004).

A commitment to honouring the Indigenous Māori in ECCE in Aotearoa has repeatedly been expressed in ECCE policy and curriculum materials since the Meade (1988) report, Education to be more, which articulated a values foundation that included recognition of Te Tiriti o Waitangi and support for not only Māori, but also diverse cultures present within ECCE settings. In the two decades since Te Whāriki (New Zealand Ministry of Education, 1996) reinforced and expanded on this commitment, there have been wide-ranging changes to the early childhood sector which are directly related to government policy. The incursion of neo-liberalism is discussed later in this article.

\section{Challenges in the implementation of Te Whāriki}

Twenty years since its publication, implementation of the 'bicultural' intent of Te Wharriki remains a challenge to the sector. Key to this enactment is a deep respect for and engagement with the language, values and cultural practices of the tangata whenua (Indigenous 'people of the land'). A 2012 national report by the New Zealand Education Review Office is revealing:

\footnotetext{
Unfortunately most centres demonstrated limited partnership with whānau Māori [Māori families]. Ninety percent did not work in partnership with whānau Māori and expected that Māori children and their whānau would 'fit in' to the centre's culture. Some made deficit assumptions about why Māori were not involved, such as claiming that Māori did not value education. Others expressed views that demonstrated their lack of understanding of whānau skill, knowledge and expertise such as 'whānau are incapable of helping with learning'. The professional leaders in these services were driven by the notion that all children and families must be 'treated the same'.
}

The view of partnership held by these services was limited and did not extend past good relationships. Most professional leaders in early childhood services had yet to realise the potential of partnership to provide a bicultural programme that fully supported the language, culture and identity of Māori children and their whānau, and to increase Māori in early childhood education. Many interactions and relationships 
established with Māori failed to reflect Māori ways of interacting and relationship building. Educators and managers waited for Māori to come to them, and face-to-face communication was limited so services assumed that Māori whānau were uninterested in developing relationships. (Education Review Office, 2012: 15)

\section{A 2013 report echoes these concerns:}

Many services made reference to Te Tiriti o Waitangi and to New Zealand's dual cultural heritage and bicultural practice in their philosophy statements. However, only a few services were fully realising such intent in practice by working in partnership with whānau Māori and through the provision of a curriculum that was responsive to the language, culture and identity of Māori children. (Education Review Office, 2013: 13)

It appears that many teachers are not equipped with the sense of concern or pedagogical capacities which would demonstrate that te ao Māori ('the Māori world') matters to them as teachers, despite this being a clearly and oft-repeated professional requirement.

More recently, New Zealand has been recognised as a 'superdiverse' country (Royal Society of New Zealand, 2013; Spoonley, 2015). This raises the serious question, two decades on from the introduction of Te Wharriki, as to how teachers who have yet to honour the intentions in the curriculum with regard to the Māori people, their language and cultural values, might be positioned with regard to supporting the languages and cultures of other diverse ethnic groups present in their early childhood settings. A further challenge to educators in Aotearoa is to prepare students with the dispositions or qualities that will enable them to advocate on behalf of a land that is being devastated by anthropogenic climate change and by western farming practices which stress and pollute the earth and rivers (Ministry for the Environment, 2015; Parliamentary Commissioner, 2004, 2014). Indigenous storyteller Thomas King (2005) has reminded us of the importance and powerful influence of the stories we tell. What are some of the stories that we have been telling ourselves, and that we have been told by policymakers, about 'quality' in ECCE? And how might we change these stories to reflect a different sensibility - a different set of qualities that reflect our embodied beingness with(in) our world?

\section{Story I. The impacts of neo-liberalism on quality/qualities in ECCE}

The elevation of neo-liberalism as the dominant economic doctrine has filtered directly into education and social services in Aotearoa. Some of these policies have included an emphasis on participation rather than high-quality provision; compulsory participation in ECCE for children of beneficiaries; the promotion of a 'free market' for the profit-oriented ECCE 'industry'; and a narrowing focus of what constitutes 'quality' provision.

Participation by infants, toddlers and young children in early childhood services has more than doubled, from just over 50\% in 1998 (Guild and Guild, c. 1999) to almost full participation (95.6\%) in 2014 (Education Counts, 2014a). The vast majority of the increase in provision has been enabled by the growth of the private sector - the early childhood 'industry' - which has profit rather than quality as its key objective (George, 2008; Mitchell, 2008). Whilst previous (Labour) government policy had aimed for a fully qualified sector by 2012 (New Zealand Ministry of Education, 2002), with the change of government (to National) in 2008 this requirement was reduced to a minimum of $50 \%$ of staff needing to hold a teaching qualification. Whereas the previous Māori education strategy had aimed for high-quality, culturally responsive early childhood provision (New Zealand Ministry of Education, 2008), current policy aims primarily at increased participation, with 
beneficiaries required to meet their 'social obligations' by ensuring that their over-three-year-old children attend an approved service or face cuts to their benefits (New Zealand Government, 2013).

Neo-liberal policies have guided the rapid expansion of an ever-burgeoning corporate sector of early childhood provision (Mitchell, 2014a, 2014b), with concomitant impacts on the not-for-profit community sector, resulting in declining enrolments in kindergarten, Playcentre and Te Kōhanga Reo (Education Counts, 2014b). These traditional services are also feeling pressure to compete with the private providers, which means, for example, that the previously sessional kindergarten service is now almost across the board offering full-day provision (Education Counts, 2014a).

The Waitangi Tribunal investigates claims by Māori regarding grievances related to breaches of Te Tiriti o Waitangi. A recent report written in response to a claim by the Te Kōhanga Reo National Trust states that:

the early childhood education sector reforms that commenced over the period from 2000 to 2011 have resulted in the Crown developing an early childhood education policy framework, quality measures, funding mechanisms and a regulatory regime that have not focused on the particular circumstances and environment of kōhanga reo to any significant degree, but have rather concentrated on incentivising participation in mainstream early childhood education services. (Waitangi Tribunal, 2013: xvi)

Whilst government policy focuses primarily on 'priorities' such as increasing participation within the sector, the lens has shifted away from what experiences children are having within early childhood education settings. As noted earlier, there has been little progress within the sector in realising aspirations for engaging with Māori families, and protecting their language and culture, as promised in Te Tiriti o Waitangi and supported by Te Whäriki. The quality or qualities of that participation no longer appears to be the priority, despite the rhetoric regarding promotion of 'participation in high quality early childhood education that is culturally responsive' (New Zealand Ministry of Education, 2008: 4; my emphasis).

The seemingly single-minded focus on the participation of not only young children in education, but also of non-working parents within the workforce, has led to penalties being imposed on beneficiaries who do not have their young children enrolled within a government-approved early childhood programme as part of their 'social obligations' (Bennett, 2012). In 2012, the New Zealand National Party-led government introduced a programme of 'Better Social Policies', which would be measured by targeted outcomes. Early childhood participation was targeted to increase and, in tandem with this, new 'social obligations' for those in receipt of government benefits included a requirement for 'all beneficiary parents to ensure their children attend 15 hours a week Early Childhood Education (ECE) from age 3' (Bennett, 2012). The then Minister for Social Development, Paula Bennett, stated that:

We are mindful there may be barriers like geographical location or capacity so parents will need to make reasonable steps to achieve these goals. But where barriers do not exist and parents don't meet these obligations, graduated sanctions could apply. (Bennett, 2012)

The minister's press release further explains that: 'The graduated sanction process will see parents receive three reminder opportunities to comply before a maximum 50 per cent financial sanction applies' (Bennett, 2012). This is reminiscent of punitive, behaviourist 'three strikes and you're out' policies that have featured elsewhere in education and justice policies (Kohn, 1996; Shichor, 1997).

Meanwhile, early childhood scholars have critiqued the shift in ECCE discourse on the New Zealand Ministry of Education's website, from a previous focus on supporting high-quality childcentred provision to one of 'schoolification', whereby previous terminologies such as 'care' and 
'development' are now replaced by a narrowed focus on 'learning' (Alcock and Haggerty, 2013). In the primary education sector, 'national standards' for literacy and numeracy, imposed in 2007, have been demonstrated to be harmful to children's education in numerous ways, which include, for example, increased teacher workload and stresses and tension amongst staff; the narrowing of the curriculum; the positioning and labelling of children, including visible wall displays of children's 'achievement' generating negative self-images amongst children and parental concern in this regard; and parental fixation on 'below/at/above the standard', rather than a more holistic view of the child's learning (Thrupp, 2014). As John O'Neill and Paul Adams have written, in this neoliberal educational experiment:

Official 'targets', 'outcomes' and 'priorities' have very little to do with a genuinely child-centred education. The child at the centre of this 'outcomes' view of education is a cipher or avatar, not a person, while the performative teacher is required to view pedagogy as the science of continuously improving student outcomes and is employed merely to ensure the Ministry can efficiently deliver its core business functions. The interests being served by this sterile vision of learning are governments, not those of children, families and communities. (O’Neill and Adams, 2012: 1)

This is a story in which ECCE in Aotearoa, originally and for many years a grass-roots, community-responsive, family-oriented, child-centred cluster of not-for-profit organisations (May, 2009, 2013), has now become an instrument of punishment and control for families that are reliant on government benefits. The emphasis on increased participation statistics has not only brought a reduction in the quality-related expectations regarding fully qualified staffing, but is also at the expense of beneficiary families' capacity to choose to spend time at home with their young children. There appears to be a conflict here with the espoused neo-liberal value of 'free choice': if you happen to be a beneficiary parent, you must place your child aged over three in an ECCE setting for a minimum of 15 hours per week or the whole family will face severe financial penalties.

The hegemonic pervasiveness of neo-liberal 'reforms' is such that it may be difficult to imagine otherwise (Moss, 2015; Sims and Waniganayake, 2015). However, our positioning in the age of the Anthropocene means that it has become urgent that we explore other theoretical lenses for opening up these spaces and sharing these imaginings. Children require more than just numeracy and literacy skills to be equipped for the challenges ahead of them. In the next story, I describe some dispositions that reflect Māori and Samoan world views, demonstrating qualities that are culturally preferred, the use of which may resonate with the inclusion rather than 'othering' of those who are not from the 'mainstream' dominant culture.

\section{Story 2. Opening up spaces for consideration of dispositional qualities}

Te Whāriki offers a dispositional approach to the early years curriculum. Its introduction states that:

Each community to which a child belongs, whether it is a family home or an early childhood setting outside the home, provides opportunities for new learning to be fostered: for children to reflect on alternative ways of doing things; make connections across time and place; establish different kinds of relationship; and encounter different points of view. These experiences enrich children's lives and provide them with the knowledge, skills, and dispositions they need to tackle new challenges. (New Zealand Ministry of Education, 1996: 9)

Te Whāriki focuses on 'dispositions for learning' (my emphasis), which are broadly positioned in alignment with key strands of the curriculum: 'Dispositions to learn develop when children are 
Table I. Possible alignment of resources across learning dispositions and key competencies.

\begin{tabular}{|c|c|c|c|c|}
\hline Te Whāriki strand & $\begin{array}{l}\text { Te Whāriki } \\
\text { strand }\end{array}$ & $\begin{array}{l}\text { Learning } \\
\text { disposition as } \\
\text { actions }\end{array}$ & Key competencies & Mediating resources \\
\hline Mana whenua & Belonging & Taking an interest & $\begin{array}{l}\text { Participating and } \\
\text { contributing }\end{array}$ & $\begin{array}{l}\text { Communities that } \\
\text { connect with the learners' } \\
\text { funds of knowledge, and } \\
\text { suggest 'possible selves' } \\
\text { and interests }\end{array}$ \\
\hline Mana atua & Well-being & Being involved & Managing self & $\begin{array}{l}\text { Local resources and } \\
\text { routines that can be } \\
\text { orchestrated by teachers } \\
\text { and learners }\end{array}$ \\
\hline Mana aotūroa & Exploration & $\begin{array}{l}\text { Persisting with } \\
\text { uncertainty and } \\
\text { challenge }\end{array}$ & Thinking & $\begin{array}{l}\text { Ways of thinking and } \\
\text { exploring }\end{array}$ \\
\hline Mana reo & Communication & $\begin{array}{l}\text { Expressing ideas } \\
\text { and feelings }\end{array}$ & $\begin{array}{l}\text { Using language, } \\
\text { symbols and texts }\end{array}$ & $\begin{array}{l}\text { Diverse languages, } \\
\text { symbols and texts }\end{array}$ \\
\hline Mana tangata & Contribution & $\begin{array}{l}\text { Taking } \\
\text { responsibility }\end{array}$ & Relating to others & $\begin{array}{l}\text { Other people, in a range } \\
\text { of roles }\end{array}$ \\
\hline
\end{tabular}

Source: Carr (2006: 25).

immersed in an environment that is characterised by well-being and trust, belonging and purposeful activity, contributing and collaborating, communicating and representing, and exploring and guided participation' (44). Margaret Carr (2006) has aligned a set of learning dispositions with these strands and with the New Zealand school curriculum's 'key competencies', as shown in Table 1.

The work of Carr and her colleagues (New Zealand Ministry of Education, 2004, 2007, 2009) has been significant in generating and validating a model of narrative assessment within the ECCE sector in New Zealand. However, concerns that this model did not sufficiently represent Māori world views led the Ministry of Education to produce a Māori assessment document, Te Whatu Pōkeka (New Zealand Ministry of Education, 2009). This document invites teachers to locate their ways of relating to and understanding Māori children within a Māori cosmological framework that recognises the wairua ('spiritual well-being'), mana ('integrity', 'power'), tapu ('sanctity') and mauri ('life force') of the child.

Te Whatu Pōkeka contains examples of qualities that are referenced by the teachers in the project to develop this kaupapa Māori ('Māori philosophy') assessment framework. One ECCE centre utilised the legends associated with the accomplishment of demigod Maui to identify the following aspirational qualities, which they could then recognise and affirm in their children:

Mana: identity - pride - inner strength

Manaakitanga/aroha: caring - sharing - kindness - supporting others - being a friend

Whakakata: humour - fun

Tinihanga/whakatoi: cunning - trickery - cheekiness

Pātaitai/kaitoro: testing - challenging - questioning - curiosity - exploring - risk-taking

Arahina/māiatanga: confidence - self-reliance - leadership - perseverance - self-assurance

Māramatanga: developing understandings - working through difficulty - lateral thinking

Ngāhononga: tuakana-teina [older children supporting younger children] - ako [learning/teaching] whanaungatanga [relationships]. (New Zealand Ministry of Education, 2009: 60) 
These qualities emerge from a shared whakapapa (the layering of ancestral connections of intergenerational genetic and knowledge transferral), which is connected intimately to mana whenua (the authority of belonging to a specific tribal genealogy linked to place) and, ultimately, to Papatūānuku (the Earth Mother) and Ranginui (the Sky Father).

Teachers in a kindergarten located in a community of predominately Māori and Pacific Islands peoples have a wall display which shows how they have begun using a set of 'Samoan dispositions' to guide their understandings of children's experiences. This is the list which was gifted to them by a Samoan colleague, and which draws on the work of Luafutu-Simpson (2011):

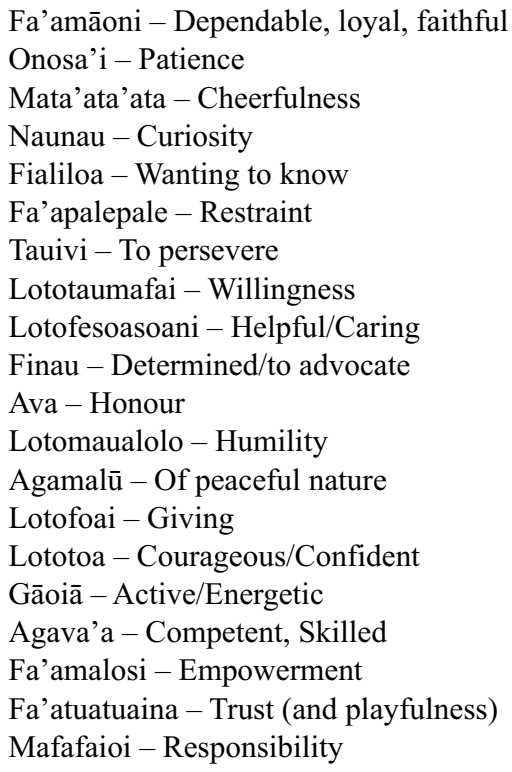

These dispositions can be viewed in the context of cultural values that reinforce fa'aaloalo ('respect') and collective, distributed responsibility, whereby traditionally caregivers routinely encourage infants to 'notice, accommodate, and anticipate needs of others' (Ochs and Izquierdo, 2009: 397). This is indeed an interesting story and one in which 'learning' (or, more fulsomely, being, knowing, doing and relating) happens through trusting, respectful collaborative relationships, within communities with shared genealogies of understandings.

Different ethnic groups have culturally preferred qualities, such as the high value placed on omoiyari ('empathy') in Japanese early childhood practices (Hayashi et al., 2009). Through this focus on nurturing a sense of empathy, Japanese early childhood teachers foster children's capacity to recognise and engage with not only the obvious, but also the more subtle manifestations of other children's emotional well-being, requiring attention to 'the ability to be aware of the unverbalized or awkwardly expressed feelings of others' (Hayashi et al., 2009: 46). Hayashi et al. explain the emphasis on generating a collective sense of intersubjectivity in Japanese early childhood pedagogy:

Within the Japanese preschool's pedagogy of feeling, among the most highly valued feelings are sabishii-sa (loneliness) and amae (dependence). Sabishii-sa, or loneliness, is emphasized more so than, for example, anger or embarrassment because this feeling is seen to provoke responses of omoiyari and to fuel the desire for sociality, which are core curricular goals of the Japanese preschool. Loneliness and sociality are reciprocally connected: Feeling lonely motivates people to seek the company of others. Expressions of 
loneliness, in turn, provoke the empathic response of inviting the lonely person to join the group. Shared experiences of talking about and both directly and vicariously experiencing loneliness provide a sense of intersubjectivity that strengthens group ties. (Hayashi et al., 2009: 46)

Whilst western conceptualisations of interdependence are predominately humanist, focusing on interrelationships between people (Raeff, 2006), Indigenous perspectives are inclusive of both more-than-humans and humans. As Shawn Wilson, an Opaskwayak Cree from northern Manitoba has written:

Identity for Indigenous peoples is grounded in their relationships with the land, with their ancestors who have returned to the land, and with future generations who will come into being on the land. Rather than viewing ourselves as being in relationship with other people or things, we are the relationships that we hold and are part of. (Wilson, 2008: 80)

Dispositions for relating with both human and more-than-human others must surely be a part of this story that is yet to unfold. Yet, despite the imperative of impending climate crisis requiring empathic re-engagement by humanity with the more-than-human world, and the potential for ECCE settings to enable this compassion (Ritchie et al., 2010), a study of 357 US pre-service and practising early childhood teachers found that 'they rated the curricular domain of nature $=$ science as the least important for young children in terms of experiences and learning outcomes in comparison to other curricular domains' (Torquati et al., 2013: 721). In Aotearoa, a lack of opportunities to engage with the more-than-human world is being exacerbated by the narrowing of the curriculum to prioritise numeracy and literacy. This raises the concern that these policies may result in distancing children from enacting qualities of compassionate engagement with(in) it. This seems to imply a disengagement from the sensory receptivity that many Indigenous peoples describe as a core part of their lived interdependence with the more-than-human realm. Sensory engagement is the focus of the next, and final, story, which is based on recent observations in a kindergarten with a high enrolment of Māori and Pacific Islands families.

\section{Story 3. Qualities of holistic, sensory engagement with(in) the world}

I have noticed that the children at the kindergarten where I have recently been spending time are often creating their own games, intra-acting with materials that have resonance for them. One collective game involved throwing trucks into a large puddle, generating satisfying splashes, and then retrieving them in a repeated cycle, with communication between the participants ensuring careful timing of the retrievals in order to avoid being hit by a flying truck, although not necessarily avoiding being splattered with muddy water. Another game, which also lasted for an extended period, featured a group of boys making repeated attempts, and the communication and negotiation of multiple strategies, using large, sharp metal shovels as axes and levers to dig, prise and chop in order to release and then cut through a tree root that had been partially buried. Once again, tacit understanding of the imminent danger, as well as shouted warnings to alert the others, allowed the boys to avoid injury.

In considering how we might move beyond the confines of a humanist, cognitivist, individualistic dispositional lens, the work of Hillevi Lenz Taguchi is informative. She draws on the work of Haraway, Barad, Aliamo, and Deleuze and Guattari to describe a methodology of 'diffractive analysis', which she focuses on 'transcorporeal engagements' that are holistically and sensorially focused. Lenz Taguchi's approach requires attentiveness 'to those bodymind faculties that register 
smell, touch, level, temperature, pressure, tension and force in the interconnections emerging in between different matter, matter and discourse'. Lenz Taguchi proposes that researchers (and, by extension, children and teachers, who I see as researchers within their learning and teaching contexts) implement this process of diffractive analysis, using embodied sensory awareness to avoid being locked into humanist, cognitivist, discursive modes of recognition and representation (Lenz Taguchi, 2012: 267).

The children in the activities described above are deeply engrossed in a holistic 'bodymind' intra-action with both more-than-human and human others. This depth of sensory, embodied engagement enables their response-ability within these intra-actions, enabling avoidance of the physical impact of the forces of thrown trucks or of metal shovels being propelled as axes. Their ethic of response-ability to the collective urges them to communicate warnings, which contribute to each other's well-being. The teachers at this kindergarten, who are deeply respectful of children's engagement with the forces around them, resist the urge to respond to professional standards of 'quality' with regard to 'health and safety', and instead recognise the qualities of intra-active engagement that transcend these normative notions.

The overarching statement for the Te Whāriki principle of ngā hononga ('relationships') is that: 'Children learn through responsive and reciprocal relationships with people, places, and things' (New Zealand Ministry of Education, 1996: 43). This reflects the te ao Māori ('Māori world view') partnership process of the development of the document, and thus an Indigenous recognition of what the Vietnamese Buddhist teacher Thich Naht Hanh (1991) terms 'interbeing'. Recognising and responding to the climate crisis requires a rebalancing of our relationships with(in) our planet (Dockstator, 2014), moving beyond humanistic, neo-liberal frames, and sharing the recognition upheld by Indigenous peoples that everyday practices should be conducted in appreciation of and intra-action with the shared life forces that both infuse and surround us.

\section{Declaration of conflicting interests}

The author declares that there is no conflict of interest.

\section{Funding}

This research received no specific grant from any funding agency in the public, commercial or not-for-profit sectors.

\section{Note}

1. I deliberately italicise the end of the word 'qualities' to maintain an emphasis on the multiplicity of the focus required, and to signal an avoidance of the genericised, homogenised understandings often associated with the notion of 'quality'.

\section{References}

Alcock S and Haggerty M (2013) Recent policy developments and the 'schoolification' of early childhood care and education in Aotearoa New Zealand. Early Childhood Folio 17(2): 21-26.

Barad K (2003) Posthumanist performativity: Toward an understanding of how matter comes to matter. Signs 28(3): 801-831.

Bennett P (2012) Social obligations mean better outcomes for children. Available at: http://beehive.govt.nz/ release/social-obligations-mean-better-outcomes-children

Braidotti R (2013) The Posthuman. Cambridge: Polity Press.

Cameron E, Shine T and Bevins W (2013) Climate justice: Equity and justice informing a new climate agreement. Working paper, September. Washington, DC: World Resources Institute. Available at: http:// www.wri.org/publication/climate-justice-equity-and-justice-informing-new-climate-agreement 
Carr M (2006) Learning dispositions and key competencies: A new curriculum continuity across the sectors? Set 2: 23-27.

Dockstator JS (2014) Widening the Sweetgrass Road: Re/balancing ways of knowing for sustainable living with a Cree-Nishnaabe medicine circle. PhD Thesis, York University, Toronto, ON, Canada.

Education Counts (2014a) Annual ECE census report 2014. Wellington, New Zealand: Ministry of Education. Available at: https://www.educationcounts.govt.nz/statistics/early-childhood-education/annual-ecesummary-reports

Education Counts (2014b) Participation in early childhood education. Available at: https://www.educationcounts.govt.nz/indicators/main/student-engagement-participation/1923

Education Review Office (2012) Partnership with whānau Mäori in early childhood services. Wellington, New Zealand: Education Review Office. Available at: http://www.ero.govt.nz/National-Reports/ Partnership-with-Whanau-Maori-in-Early-Childhood-Services-Feb-2012

Education Review Office (2013) Working with Te Whäriki. Wellington, New Zealand: Education Review Office. Available at: http://www.ero.govt.nz/National-Reports/Working-with-Te-Whariki-May-2013

George R (2008) The pursuit of profit in education: The penetration of business into the early childhood and primary schooling sectors. New Zealand Journal of Teachers' Work 5(1): 13-20.

Goldenberg S (2014) Climate change a threat to security, food and humankind - IPCC report. The Guardian, 31 March. Available at: http://www.theguardian.com/environment/2014/mar/31/climate-change-threatfood-security-humankind

Guild DE and Guild RL (c.1999) Educational opportunity across the Auckland region: The relationship between early childhood facilities and demographic and socio-economic characteristics. ACE Papers 5: 54-63. Available at: https://researchspace.auckland.ac.nz/handle/2292/25057

Hanh TN (1991) Peace Is Every Step: The Path of Mindfulness in Everyday Life. New York: Bantam Books.

Hanh TN (2008) The World We Have: A Buddhist Approach to Peace and Ecology. Berkeley, CA: Parallax Press.

Haraway D (2012) Awash in urine: DES and Premarin ${ }^{\circledR}$ in multispecies response-ability. Women's Studies Quarterly 40(1-2): 301-316.

Hayashi A, Karasawa M and Tobin J (2009) The Japanese preschool's pedagogy of feeling: Cultural strategies for supporting young children's emotional development. Ethos 37(1): 32-49.

Jenkins K and Harte HM (2011) Traditional Maori parenting: An historical review of literature of traditional Maori child rearing practices in pre-European times. Available at: http://www.ririki.org.nz/index.php/ what-we-do/our-research

King T (2005) The Truth about Stories: A Native Narrative. Minneapolis, MN: University of Minnesota Press.

Kohn A (1996) Beyond discipline. Education Week, 20 November. Available at: http://www.alfiekohn.org/ article/beyond-discipline-article/

Latour B (2004) Why has critique run out of steam? From matters of fact to matters of concern. Critical Inquiry 30(2): 225-248.

Lenz Taguchi H (2012) A diffractive and Deleuzian approach to analysing interview data. Feminist Theory 13(3): 265-281.

Levinas E (1987) Time and the Other. Trans. Cohen RA. Pittsburgh, PA: Duquesne University Press.

Luafutu-Simpson P (2011) Exploring the teaching of effective approaches for assessing young Samoan children's learning in early childhood centres: Developing an authentic Samoan lens. Wellington, New Zealand: Ako Aotearoa National Centre for Tertiary Teaching Excellence. Available at: https:// akoaotearoa.ac.nz/ako-hub/ako-aotearoa-southern-hub/resources/pages/developing-authentic-samoanlens

May H (2009) Politics in the Playground: The World of Early Childhood in New Zealand. 2nd ed. Dunedin, New Zealand: Otago University Press.

May H (2013) The Discovery of Early Childhood. 2nd ed. Wellington, New Zealand: NZCER Press.

Meade A (1988) Education to be more: Report of the Early Childhood Care and Education Group. Wellington, New Zealand: Government Printer. 
Ministry for the Environment and Statistics New Zealand (2015) Environment Aotearoa 2015. Wellington, New Zealand: Ministry for the Environment and Statistics New Zealand. Available at: http://www.mfe. govt.nz/publications/environmental-reporting/environment-aotearoa-2015?_ga=1.7223345.203854307 6.1445667533

Mitchell L (2008) Early Childhood Education Services in 2007: Key Findings from the NZCER National Survey. Wellington, New Zealand: New Zealand Council for Educational Research.

Mitchell L (2014a) Alternatives to the market model: Reclaiming collective democracy in early childhood education and care. Early Education 55: 5-8.

Mitchell L (2014b) Linda Mitchell: Put children's education before shareholders. New Zealand Herald, 2 December. Available at: http://www.nzherald.co.nz/politics/news/article.cfm?c id $=280 \&$ objectid $=11367139$

Moss P (2015) There are alternatives! Contestation and hope in early childhood education. Global Studies of Childhood 5(3): 226-238.

Moss P, Dahlberg G and Pence A (2000) Getting beyond the problem with quality. European Early Childhood Education Research Journal 8(2): 103-115.

New Zealand Government (2013) Obligations for people on a benefit with dependent children. Available at: $\mathrm{http} / /$ www.workandincome.govt.nz/individuals/benefit-changes/obligations-for-people-on-a-benefitwith-dependant-children.html

New Zealand Ministry of Education (1996) Te Whāriki: He Whāriki Mātauranga mō ngā Mokopuna o Aotearoa: Early Childhood Curriculum. Wellington, New Zealand: Learning Media. Available at: http:// www.education.govt.nz/early-childhood/teaching-and-learning/ece-curriculum/te-whariki/

New Zealand Ministry of Education (2002) Pathways to the Future: Ngā Huarahi Arataki. A 10-Year Strategic Plan for Early Childhood Education. Wellington, New Zealand: Ministry of Education.

New Zealand Ministry of Education $(2004,2007,2009)$ Kei Tua o te Pae/Assessment for Learning: Early Childhood Exemplars. Wellington, New Zealand: Learning Media.

New Zealand Ministry of Education (2008) Ka Hikitia/Managing for Success: Mãori Education Strategy 2008-2012. Wellington, New Zealand: Ministry of Education. Available at: http://www.parliament.nz/ resource/en-nz/49SCMA_EVI_00DBSCH_INQ_9064_1_A14037/0449a92c3574c1e5b0f850ae1fdb15 5 b155fe3aa

New Zealand Ministry of Education (2009) Te Whatu Pōkeka: Kaupapa Māori Assessment for Learning. Early Childhood Exemplars. Wellington, New Zealand: Learning Media. Available at: http://www.education.govt.nz/assets/Documents/Early-Childhood/TeWhatuPokeka.pdf

Ochs E and Izquierdo C (2009) Responsibility in childhood: Three developmental trajectories. Ethos 37(4): 391-413.

O'Neill J and Adams P (2012) 'Damned to mediocrity': Political targets, bureaucratic intent, classroom performativity and the child as cipher. New Zealand Journal of Teachers' Work 9(1): 1-5.

Parliamentary Commissioner for the Environment/Te Kaitiaki Taiao a Te Whare Pāremata (2004) See Change: Learning and Education for Sustainability. Wellington, New Zealand: Parliamentary Commissioner for the Environment.

Parliamentary Commissioner for the Environment/Te Kaitiaki Taiao a Te Whare Pāremata (2014) Changing Climate and Rising Seas: Understanding the Science. Wellington, New Zealand: Parliamentary Commissioner for the Environment. Available at: http://www.pce.parliament.nz/our-work/news-insights/ environment-commissioner-warns-of-impact-from-rising-seas

Puig de la Bellacasa M (2012) 'Nothing comes without its world': Thinking with care. Sociological Review 60(2): 197-216.

Raeff E (2006) Individuals in relation to others: Independence and interdependence in a kindergarten classroom. Ethos 34(4): 521-557.

Ritchie J (2013) Indigenous onto-epistemologies and pedagogies of care and affect in Aotearoa. Global Studies of Childhood 3(4): 395-406.

Ritchie J, Duhn I, Rau C, et al. (2010) Titiro whakamuri, hoki whakamua. We are the future, the present and the past: Caring for self, others and the environment in early years' teaching and learning. Final Report for the Teaching and Learning Research Initiative. Wellington, New Zealand: Teaching and Learning 
Research Initiative. Available at: http://www.tlri.org.nz/tlri-research/research-completed/ece-sector/ titiro-whakamuri-hoki-whakamua-we-are-future-present-and

Rose D (2009) Love in the time of extinctions. Australian Journal of Anthropology 19(1): 81-84.

Royal Society of New Zealand (2013) Languages in Aotearoa New Zealand. Wellington, New Zealand: Royal Society of New Zealand. Available at: http://www.royalsociety.org.nz/expert-advice/informationpapers/yr2013/languages-in-aotearoa-new-zealand/

Shichor D (1997) Three strikes as a public policy: The convergence of the new penology and the McDonaldization of punishment. Crime and Delinquency 43(4): 470-492.

Sims M and Waniganayake M (2015) The performance of compliance in early childhood: Neoliberalism and nice ladies. Global Studies of Childhood 5(3): 333-345.

Spoonley P (2015) New diversity, old anxieties in New Zealand: The complex identity politics and engagement of a settler society. Ethnic and Racial Studies 38(4): 650-661.

Taylor A and Pacini-Ketchabaw V (2015) Learning with children, ants, and worms in the Anthropocene: Towards a common world pedagogy of multispecies vulnerability. Pedagogy, Culture and Society 23(4): $507-529$.

Thrupp M (2014) At the eye of the storm: Researching schools and their communities enacting national standards. New Zealand Journal of Educational Studies 49(1): 6-20.

Torquati J, Cutler K, Gilkerson D, et al. (2013) Early childhood educators' perceptions of nature, science, and environmental education. Early Education and Development 24(5): 721-743.

Waitangi Tribunal (2011) Ko Aotearoa tēnei: A report into claims concerning New Zealand law and policy affecting Māori culture and identity. Te taumata tuarua, vol. 1. Wai 262. Wellington, New Zealand: Waitangi Tribunal. Available at: http://www.justice.govt.nz/tribunals/waitangi-tribunal

Waitangi Tribunal (2013) Matua rautia: Report on the Kōhanga Reo claim. Wai 2336. Wellington, New Zealand: Waitangi Tribunal. Available at: http://www.justice.govt.nz/tribunals/waitangi-tribunal/news/ wai-2336-matua-rautia-report-on-the-kohanga-reo-claim

Walker R (2004) Ka Whawhai Tonu Matou: Struggle without End. Rev. ed. Auckland, New Zealand: Penguin. Wilson S (2008) Research Is Ceremony: Indigenous Research Methods. Black Point, NS, Canada: Fernwood.

\section{Author biography}

Jenny Ritchie lectures at the Victoria University of Wellington School of Education. She is a qualified kindergarten teacher and has worked for 25 years in early childhood teacher education. Her current research focuses on young children's civic responsibility. 